\title{
EFFECT OF FARM MACHINERY ON SOME SOIL PHYSICAL PROPERTIES USING HYPERSPECTRAL DATA
}

Nasr, G. M. ${ }^{1}$, W. M. Abd Elkawy ${ }^{2}$,

A. H. Al-nahry ${ }^{3}$ and S. M. Abd Elhafeez ${ }^{4}$

\section{ABSTRACT}

Traditional soil analyses are expensive, time-consuming, and may also result in environmental pollutants. The objective of this study was to develop a methodology to predict soil physical properties specifically the soil bulk density using spectral reflectance (SR) as an alternative to traditional methods. Additionally to critically examine the suitability of Visible and Near-infrared (Vis- NIR) (350-2500 nm) measurements for calibration procedures and methods to predict the value of soil bulk density. Five different seedbed preparation systems were applied. Spectroradiometer ASD was used to measure the soil spectral reflectance of each system. Stepwise multiple linear regression (SMLR) was used to construct calibration models subjected to the independent validation. The obtained regression models were of good quality $\left(R^{2}=0.959,0.868\right.$, $0.811,0.751$ and 0.677 for system 5, system 1, system 3, system 4 and system 2, respectively). Thus, Visible and Near-infrared (Vis-NIR) reflection spectroscopy is cost-and time-effective procedure that can be used as an alternative to the traditional methods of measuring soil physical properties.

Keywords: seedbed preparation- physical properties- bulk densityspectral reflectance- spectroradiometer- multi linear regression (MLR)

\section{INTRODUCTION}

griculture of activities remain an important sector of the
Egyptian economy which provides the country through
agricultural exports with an important part of its foreign exchange. Due to the low volume of investments allowed to the agricultural sector over the last view years and with advances in satellite,

\footnotetext{
${ }^{1}$ Prof. of Agric. Eng. Fac. of Agric. Cairo Univ.

${ }^{2}$ Prof. of Soil Sciences. Fac. of. Agric. Cairo Univ.

${ }^{3}$ Prof. of Soil Sciences. National Authority for Remote Sensing \& Space Sciences.

${ }^{4}$ Agricultural specialist, National Authority for Remote Sensing \& Space Sciences.
} 
airborne and ground based remote sensing, reflectance data are increasingly being used in agriculture. Soil preparation is a very important operation of the grain production process. It is essential to maximize the possible yields (Valainis, et al., 2014). Remote sensing is the science of acquiring information about the Earth's surface without actually being in contact with it (Parveen et al., 2017). Remote Sensing (RS) and Geographic Information System (GIS) provided detailed spatial information on soil properties. Reflectance spectroscopy is also relatively less expensive and faster than traditional measurements (Awes, 2017). Hyperspectral remote sensing could be used to identify the spectral signature of each object. Spectral signature is the specific combination of reflected and absorbed electromagnetic radiation at varying wavelengths which can uniquely identify an object (Aboelghar and Abdel Wahab, 2013). Soil compaction, reflected by high bulk density, is an environmental degradation process and new technologies are being developed for its detection. Despite the proven efficiency of remote sensing, it has not been widely used for soil density. Soil line and spectral reflectance used together could detect soil bulk density variations for the clay soil (Demattệ et al., 2010). Many of regression models are used to estimate qualitative and quantitative analysis of the various elements in soil based on studying the relationship between each element properties and the observance for each selected wavelength (Mohamed et al., 2016). Visible/NIR spectroscopy as a powerful, fast and non-destructive technique that is increasingly used for measuring a large number of chemical and physical properties of agricultural products (Abdel-Nour, et al., 2009). The application of VNIRS are including laboratory hyperspectral measurements and field spectrometer measurements or image spectroscopy, generally achieves a good prediction of heavy metals concentrations (Al-Maliki et al., 2012). Remote sensing data could be used for the early warning of moderately and slightly infected palm, this is considered the key point used in integrated pest management system (Yones et al., 2014). The purpose of this object was followed by developing a mathematical method to automatically detect soil bulk density. A study was conducted to characterize reflectance spectra of soil 
bulk density with different seedbed preparation systems and seek to identify specific narrow wavelengths sensitive to soil bulk density.

\section{MATERIALS AND METHODS}

\subsection{The experiment layout}

The experiments were carried out at the Experimental Station, Faculty of Agriculture-Cairo University in cooperation with National Authority for Remote Sensing and Space Science (NARSS) Cairo, Egypt. The study area is located between longitude $31^{\circ} 11^{\prime} 41.39^{\prime \prime}$ and $31^{\circ} 11^{\prime} 37.74 " \mathrm{~N}$ and latitude $30^{\circ} 01^{\prime} 10.22^{\prime \prime}$ and $30^{\circ} 01^{\prime} 09.20^{\prime \prime} \mathrm{E}$ as shown in (figure 1) below. The main plot was divided into five subplots contained different tillage systems as shown in (table 1). The spectral signature was taken with four replications for each treatment and the same samples of soil were taken to measure the bulk density in the laboratory.

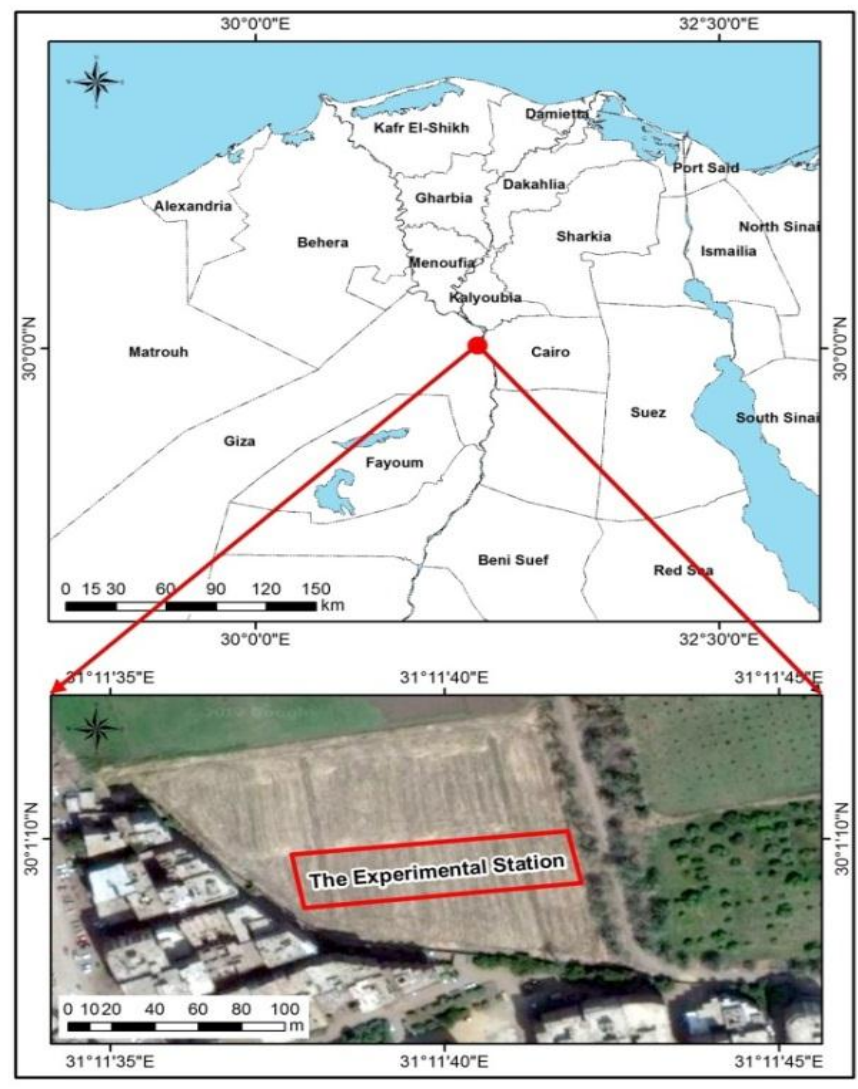

Fig. (1). The experiment layout 
Table (1): The implements of different seedbed preparation systems

\begin{tabular}{|c|c|c|c|c|}
\hline System 1 & System 2 & System 3 & System 4 & System 5 \\
\hline Disc plough & Disc Plough & $\begin{array}{l}\text { Chisel plough } \\
1^{\text {st }} \text { pass }\end{array}$ & Disc Plough & \multirow{7}{*}{ No tillage } \\
\hline $\begin{array}{l}\text { Chisel Plough } \\
1^{\text {st }} \text { pass }\end{array}$ & $\begin{array}{l}\text { Chisel Plough } \\
1^{\text {st }} \text { pass }\end{array}$ & $\begin{array}{l}\text { Chisel Plough } \\
2^{\text {nd }} \text { pass }\end{array}$ & Tooth Harrow & \\
\hline Tooth Harrow & $\begin{array}{l}\text { Chisel Plough } \\
2^{\text {nd }} \text { pass }\end{array}$ & Tooth Harrow & Land Leveler & \\
\hline Land Leveler & $\begin{array}{l}\text { Chisel Plough } \\
3^{\text {rd }} \text { pass }\end{array}$ & Land Leveler & Ridger & \\
\hline \multirow[t]{3}{*}{ Ridger } & Tooth Harrow & Ridger & & \\
\hline & Land Leveler & & & \\
\hline & Ridger & & & \\
\hline
\end{tabular}

\subsection{Tractor and seedbed preparation implements}

- The agricultural tractor (Belarus90D 243.1)

- Primary tillage implements: chisel plough and disc plough.

- Secondary tillage implement: tooth harrow and land leveler followed by ridger.

\subsection{Measuring instruments}

- GPS- Stop watch- survey instrument (linen tap and pegs).

- Graduated cylinder for measuring the consumed fuel.

- Dry oven and balance to measure bulk density.

- Penetrometer to measure soil penetration resistance.

\subsection{Spectroradiometer measurements}

A full range Spectroradiometer (from $350 \mathrm{~nm}$ to $2500 \mathrm{~nm}$ ) manufactured by Analytical Spectral Devices (ASD, FieldSpec) was used to collect spectral data. The sensor field of view was $25^{\circ}$. Data were collected on cloudless days from 10 am to $2 \mathrm{pm}$ in order to minimize external effects from the atmospheric conditions and changes in solar position. The spectroradiometer was held at nadir angle at $5 \mathrm{~cm}$ above the sample. Spectral reflectance was calculated as the ratio of measured radiance to the radiance from a white standard reference panel (Labsphere spectralon panel 99\% reflectance). 
Immediately after the white standard radiance measurement, five spectra of each sample were obtained. All of the measurements were made with the sensor located directly above the center of the sample. The mean of the five spectra was determined to provide a single spectral value.

\subsection{Removing Atmospheric Water Absorption Bands}

Under certain measure the atmosphere strongly absorbs the incident down welling radiation in three regions (1350-1450, 1800-1980 and 2350-2500) of the shortwave infrared region. As a result the reflectance data appear very noisy in these regions. The noisy bands were removed by opening the exported ASCII text files in Microsoft Excel and deleting the undesirable bands then save as Excel file.

\subsection{ViewSpec Software}

ViewSpec software used to convert spectral data from DN data to reflectance data and export it to ASCII text files, which used easily in Microsoft Excel.

\subsection{Multivariate Statistical Regression}

The stepwise multiple linear regression method was used to model the relationship between soil bulk density under different seedbed preparation systems and reflectance. Multivariate statistical regression is concentrated to find the combination which is called as the liner discriminate function against the variables and the discriminate score. The linear expression is as follows:

$$
\mathbf{y}=\mathbf{a}+\mathbf{b}_{1} \mathbf{x}_{1}+\mathbf{b}_{2} \mathbf{x}_{2}+\ldots+\mathbf{b}_{\mathbf{n}} \mathbf{x}_{\mathbf{n}}
$$

Where, $\mathrm{y}$ is the soil bulk density explained by wavelengths $\mathrm{x}_{1}, \mathrm{x}_{2}$ and $\mathrm{x}_{\mathrm{n}}$, $a$ is intercept and $b_{1}, b_{2}$ and $b_{n}$ are the regression coefficients. The final regression equation was derived through a researcher controlled trial, error approach and the impact of soil bulk density. Two main assumptions were used to check the relationships between the dependent (soil bulk density) and independent (reflectance) variables involved in multiple regression analysis.

\section{RESULTS AND DISCUSSION}

\subsection{Soil properties measurements}

(Table 2) presents the measured and calculated results of soil physical properties including the value of bulk density which were combined with 
soil spectral reflectance for different seedbed preparation systems to develop a bulk density prediction model.

Table 2. The effect of different seedbed preparation systems on some physical properties of the soil.

\begin{tabular}{ccccc}
\hline Treatments & $\begin{array}{c}\text { Bulk } \\
\text { density } \\
\left(\rho_{\mathrm{b}}\right) \\
\mathrm{g} / \mathrm{cm}^{3}\end{array}$ & $\begin{array}{c}\text { Total } \\
\text { porosity } \\
(\mathrm{E}) \\
\%\end{array}$ & $\begin{array}{c}\text { Void } \\
\text { ratio(e) }\end{array}$ & $\begin{array}{c}\text { penetration } \\
\text { resistance } \\
\mathrm{N} \mathrm{cm}^{2}\end{array}$ \\
\hline Mean of S 1 & 1.065 & 59.81 & 1.49 & 36 \\
Mean of S 2 & 1.17 & 55.85 & 1.27 & 42 \\
Mean of S 3 & 0.9225 & 65.19 & 1.87 & 28 \\
Mean of S 4 & 0.96 & 63.59 & 1.75 & 32 \\
Mean of S 5 & 1.30 & 50.94 & 1.04 & 60 \\
\hline
\end{tabular}

\subsection{Spectroradiometer Data Analysis}

Spectroradiometer (ASD Field Spec) was used to evaluate quantitative analysis to prediction models for soil bulk density under different seedbed preparation systems. Two major processes were carried out calibration and validation. Calibration process was to develop a bulk density prediction model. In this process, Multi linear regression (MLR) analysis was conducted using a stepwise. Validation process was done to check the reliability of the predicted model. The idea of using multiregression statistical analysis in the current study is to combine two factors to estimate the value of soil bulk density and other soil physical properties. One of these factors is spectral reflectance values of soil samples which were measured by Spectroradiometer (Table 3). The results showed that the overall form of the ASD spectra is quite similar among the studied soil samples. Therefore stepwise multiple linear regression (MLR) was used to describe the correlation between soil bulk density under different seedbed preparation systems and their effects on spectral reflectance.The raw data for the reflectance (spectral signature) of soil samples for different seedbed preparation system are shown in the following figure (2) appear that the reflectance values was high within spectral curve especially in near infrared (NIR) and the overall reflectance of that soil tends to increase whenever the soil was compacted 
as is the case in the treatment which weren't used any machinery in it. Which Spectral data detected high bulk density (compacted) from low bulk density (non-compacted). The intensity of spectral reflectance of high soil bulk density (compacted) samples was higher than for low bulk density (non-compacted) soils due to changes in soil structure and porosity as a result of using different seedbed preparation system.

Which the overall reflectance curve for soil samples of different seedbed preparation systems can be arranged in the following descending order:

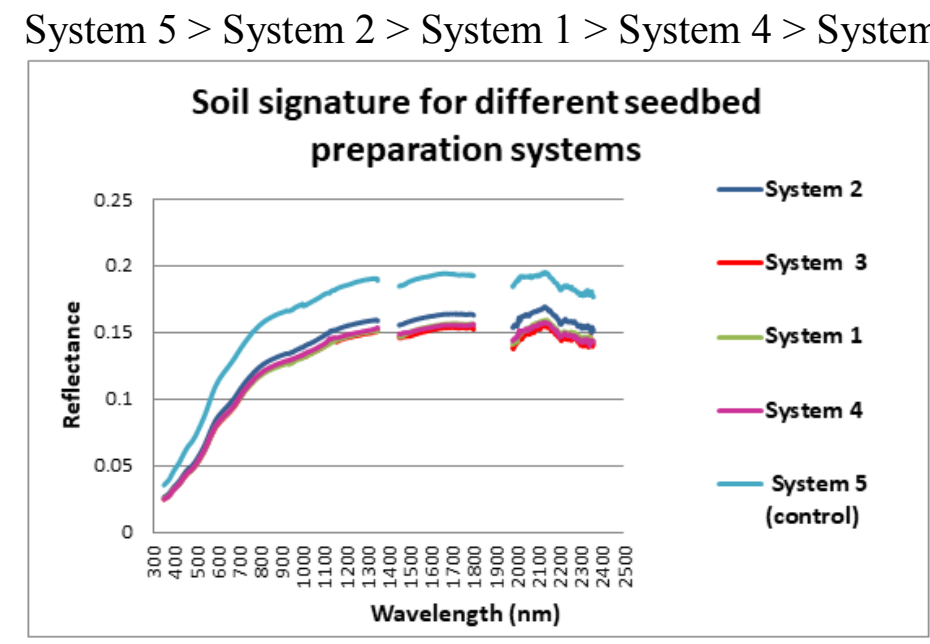

Fig.2. Relationship between soil samples (Reflectance) and wavelength

The best predictive equations were obtained for each treatment as a result of calibration processes which were selected by stepwise MLR with the highest $\mathrm{R}^{2}$ Stepwise multiple linear regression illustrated that the most affected portions of wavelength curve were (1126, 1118 and $1055 \mathrm{~nm})$ where, these regions are influenced by the value of bulk density of system 1 of soil seedbed preparation the relationship between bulk density and spectral features has been done where $(\mathrm{R} 2=0.991)$, the most affected regions on spectral reflectance were (352, 351 and $2319 \mathrm{~nm})$, (2019 and 2290nm), (947, 1985 and 2080nm) and (2358, 2324 and $2186 \mathrm{~nm}$ ) for system $2,3,4$ and 5 with $\mathrm{R}^{2}(0.954,0.851,0.989$ and 0.953$)$ respectively as shown in table (3). 
Table 3. Multi-regression models for the value of soil bulk density under different seedbed preparation systems

\begin{tabular}{|c|c|c|}
\hline Parameters & Correlation line (Models) & $\mathrm{R}^{2}$ \\
\hline $\begin{array}{l}\text { Bulk density for } \\
\text { system } 1\end{array}$ & $\begin{array}{c}1.163-4.771 * \mathrm{w} \_1126+10.253 * \mathrm{w} \_1118- \\
6.378 * \mathrm{w} \_1055\end{array}$ & 0.991 \\
\hline $\begin{array}{l}\text { Bulk density for } \\
\text { system } 2\end{array}$ & $\begin{array}{c}1.033+88.792 * \mathrm{~W} \_352-72.036 * \mathrm{w} \_351- \\
2.062 * \mathrm{w} \_2319\end{array}$ & 0.954 \\
\hline $\begin{array}{l}\text { Bulk density for } \\
\text { system } 3\end{array}$ & $0.603+4.432 * \mathrm{w} \_2019-2.341 * \mathrm{w} \_2290$ & 0.851 \\
\hline $\begin{array}{l}\text { Bulk density for } \\
\text { system } 4\end{array}$ & $\begin{array}{c}0.896-3.646 * \mathrm{w} \_947+6.046 * \mathrm{w} \_1985- \\
2.151 * \mathrm{w} \_2080\end{array}$ & 0.989 \\
\hline $\begin{array}{l}\text { Bulk density for } \\
\text { system } 5\end{array}$ & $\begin{array}{c}1.185+3.625 * \mathrm{w} \_2358- \\
6.104 * \mathrm{w} \_2324+3.036 * \mathrm{w} \_2186\end{array}$ & 0.953 \\
\hline
\end{tabular}

The relationship between measured and predicted values was plotted in figure (3, a-e). The result revealed a good relationship between the measured bulk density and the predicted ones where bulk density resulting from system 5 (no seedbed preparation) have the highest correlation with $\mathrm{R}^{2} 0.959$ followed by system 1 , system 3 and system 4 with $\mathrm{R}^{2} 0.868,0.811$ and 0.751 respectively. And the lowest value of $\mathrm{R}^{2}$ for system 2 which was 0.677 .

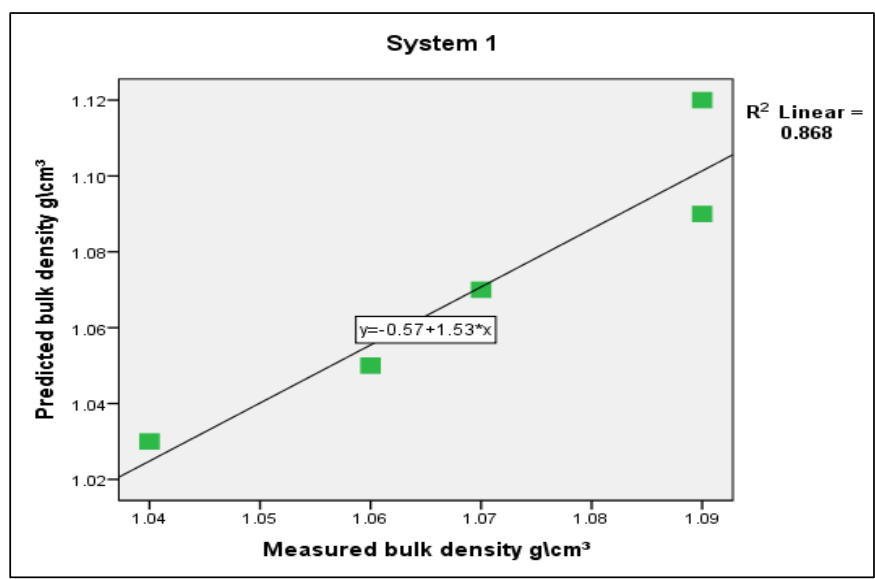

Fig.3.a. Correlation between measured and predicted soil bulk density for system 1 


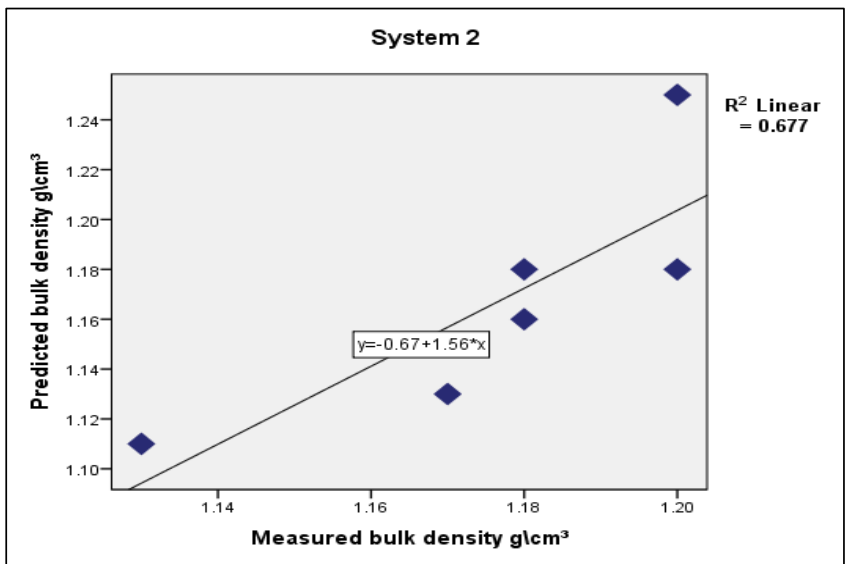

Fig.3.b. Correlation between measured and predicted soil bulk density for system 2

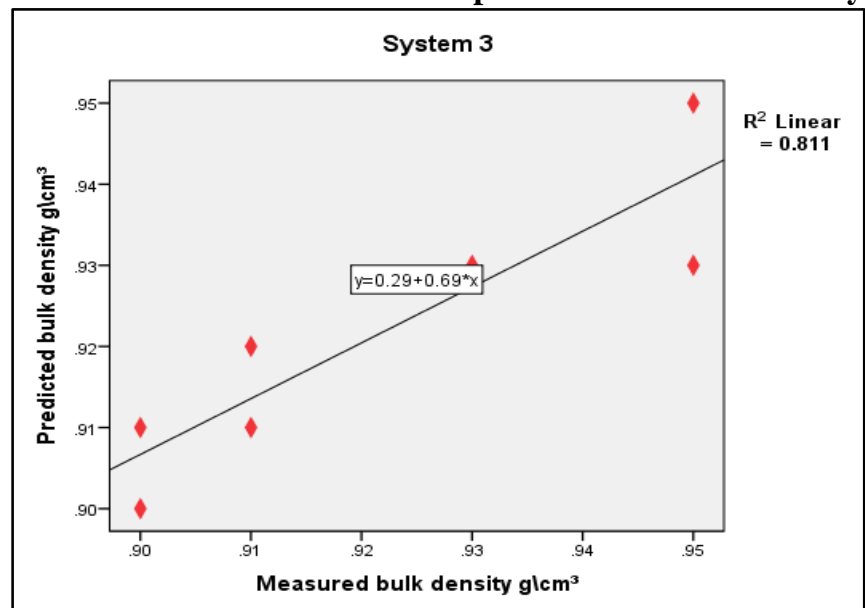

Fig.3.c. Correlation between measured and predicted soil bulk density for system 3

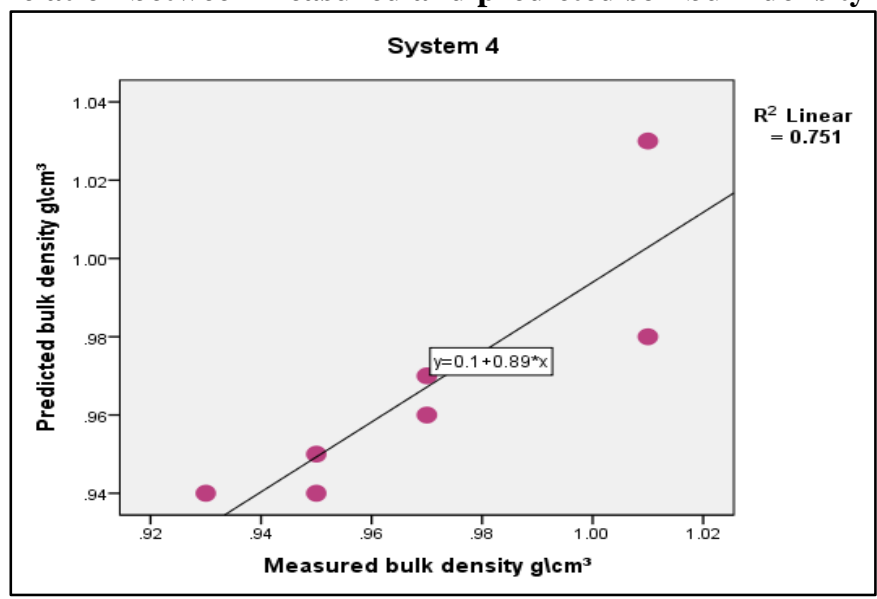

Fig.3.d. Correlation between measured and predicted soil bulk density for system 4 


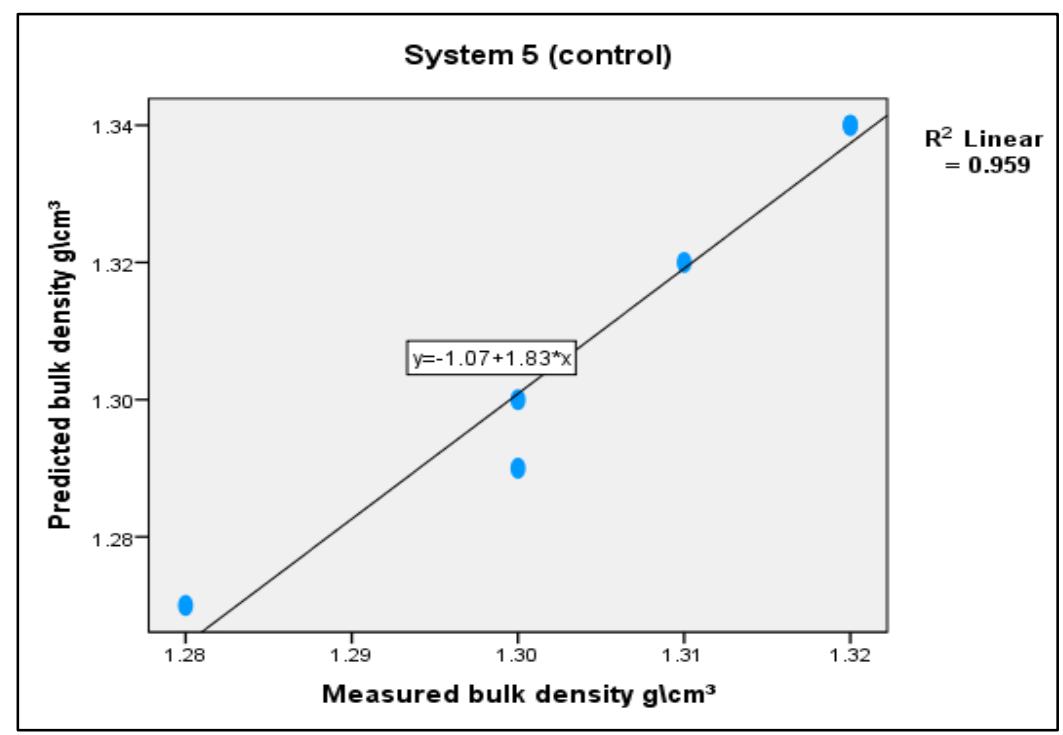

Fig.3.e. Correlation between measured and predicted soil bulk density for system 5

\section{CONCLUSION}

The present work aims to develop a new method for quantitative prediction for soil bulk density using spectroscopy techniques for different seedbed preparation systems as an alternative method to laboratory analysis. The results showed that it is possible to use spectroscopy techniques for monitoring the value of bulk density where, R2 was recorded $0.868,0.677,0.811,0.751$ and 0.959 for systems from 1 to 5 respectively. Therefore, Visible Near-infrared (Vis-NIR) reflection spectroscopy is cost and time-effective that could be alternatives to the traditional methods of bulk density analysis. In addition, it is possible measure the other physical properties of the soil resulting from the impact of the use of farm machinery which are an indicator of soil compaction, and it is considered an environmental degradation process, so it must develop this new technology to detect it. Thus, we can reduce energy costs and the environmental effects of using the farm machinery.

\section{REFERENCES}

Abdel-Nour, N.; Ngadi, M.; Prasher, M. and Karimi, Y. 2009. Combined maximum $\mathrm{R}^{2}$ and partial least square wavelengths 
selection and analysis of spectroscopic data. International Journal of poultry science, $8(2), 170-178$.

Aboelghar, M. and Abdel Wahab H. 2013. Spectral footprint of Botrytis cinerea, a novel way for fungal characterization. Advances in Bioscience and Biotechnology, 4, pp. 374-382.

Al Malikia, A.; Owens, G. and Bruce, D. 2012. Capabilities of remote sensing hyperspectral images for the detection of lead contamination. A review. Remote Sensing and Spatial Information Sciences, Volume I-7.

Awes, R. S. 2017. Detection of heavy metals contamination in southern soils of Port Said governorate using remote sensing techniques. M.Sc. Thesis, Soil and Water Dept., Fac. of Agric., Suez Canal Univ. Egypt.

Demattệ, J. A. M.; Nanni, M. R.; da Silva, A. P.; de Melo Filho, J. F.; Dos Santos, W. C. and Campos, R. C. 2010. Soil density evaluated by spectral reflectance as an evidence of compaction effects. International Journal of Remote Sensing, 31, 403-422.

Mohamed, E. S.; Ali, A. M.; El Shirbeny, M. A.; Abd El Razek Afaf A. and Savin I. Yu. 2016. Near infrared spectroscopy techniques for soil contamination assessment in the nile delta. Eurasian Soil Science, 49(6), 632-639.

Parveen, R.; Kulkarni, S. and Mytri, V. D. 2017. Study of IRS 1CLISS III image and identification of land cover features based on spectral responses. Geospatial World Forum.

Valainis, O.; Rucins, A. and Vilde, A. 2014. Technological operational assessment of one pass combined agricultural machinery for seedbed preparation and seeding. Engineering for Rural Development, 37-43.

Yones, M. S.; Aboelghar, M. A.;El-Shirbeny, M. A.; Khdry, G.A.; Ali, A. M., and Saleh, N.S. 2014. Hyperspectral Indices For Assessing Damage By The Red Palm Weevil Rhynchophorus Ferrugineus (Coleoptera: Curculionidae) In Date Palms. International Journal of Geosciences and Geomatics, 2, 16-23. 


\section{الملخص العربي \\ تأثير المعدات الزراعية علي بعض خواص التربة الطبيعية

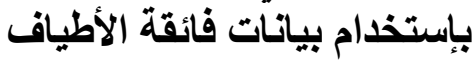 \\ أ.د. وائل محمد عبد القوي \\ أ.د. جمال الدين محمد نصر' \\ م. سمر مصطقى محمد؛

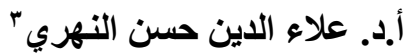

تعتبر عملية إعداد وتجهيز مرقد البذرة للمحاصيل الزراعية المختلفة من أهم العمليات التي تؤثر على الإنتاج الزراعي فإجراء هذه العمليات بالإسلوب الأمثل يحسن من خو اص التربة الطبيعية

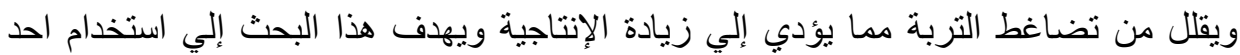

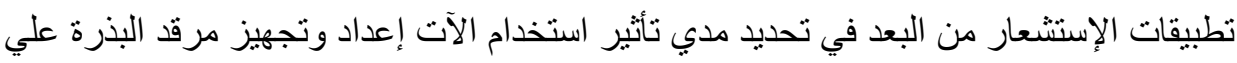

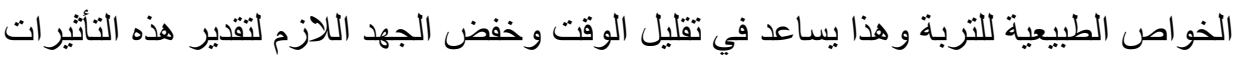
معمليا وبالتالي الوصول إلي الإستخدام الأمثل لها وذلك لتقليل الطاقة المستهلكة والاثار البيئية الضارة الناتجة عن الاستخدام المتكرر للالات الزراعية. حيث يتضمن النطاق الطيفي

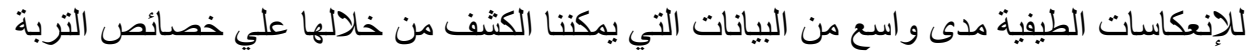

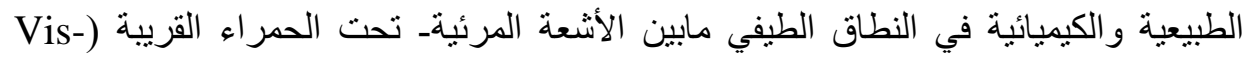
(NIR

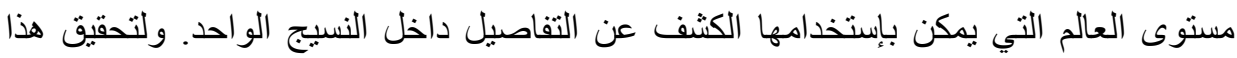
الهدف تم إعداد وتجهيز مرقد البذرة بإستخدام أنظمة مختلفة وتم أخذ عينات من التربة لإجر اء

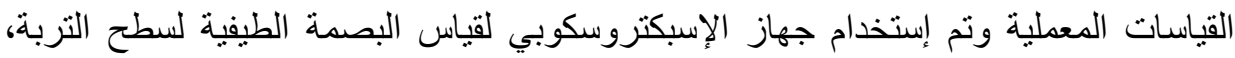
ولتحليل النتائج تم إستخدام برنامج SPSS وإستخدام الإنحدار الخطي المتعدد بطريقة stepwise

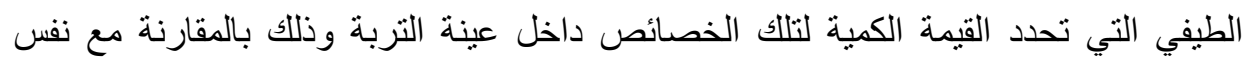
الخصائص المقاسة معمليا و إخخالهما في علاقة خطية متعددة وإستتاج تلك القيم. وقد أعطت لته

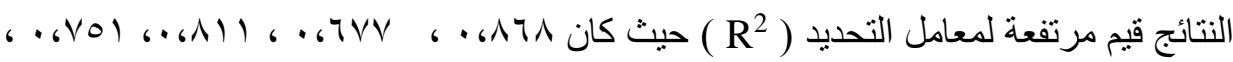
909، • للأنظمة من ا إلي ه علي الترتيب، مما يعني صلاحية تلك النماذج الرياضية للتطبيق

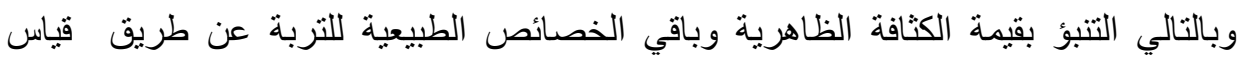
البصمه الطيفية أو الإنعكاس الطيفي لها.

' أستاذ الهندسة الزراعية، كلية الزراعة، جامعة القاهرة

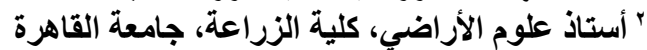

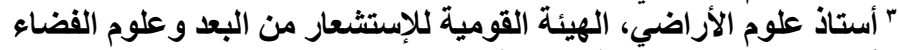

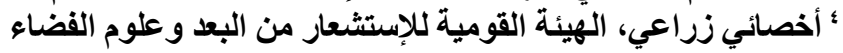

